\title{
An Assessment of The Demand for New Products of Fast Moving Consumer Goods (FMCG)
}

\author{
R. Agus Trihatmoko (Corresponding Author) \\ Doctor in Management, Faculty of Economics, and Graduate Program \\ University of Surakarta, Surakarta, Indonesia \\ E-mail: agustricentre@gmail.com \\ Saud Napitupulu \\ Doctor in Management, Department of Management \\ Sekolah Tinggi Ilmu Ekonomi Atma Bakti, Surakarta, Indonesia \\ E-mail: avatarsaud@gmail.com

\begin{abstract}
Dian Indri Purnamasari
Doctor in Accounting, Faculty of Economics and Business

Universitas Pembangunan Nasional “Veteran” Yogyakarta, Yogyakarta, Indonesia

E-mail: indri_mtc@yahoo.com
\end{abstract}

Hudi Kurniawanto

Doctor in Accounting, Faculty of Economics and Business

Universitas Slamet Riyadi, Surakarta, Indonesia

E-mail: hudi.kurniawanto@gmail.com

Received: August 24, 2018 Accepted: Sept. 11, 2018 Published: December 11, 2018

doi:10.5296/bms.v9i2.14034 URL: https://doi.org/10.5296/bms.v9i2.14034 


\begin{abstract}
Assessing the approximation of demand for a new product is a complex work, while current research on demand assessment is limited. The purpose of this paper is to identify, describe, and obtain deep understanding comprehensively about: (1) the assessment of demand by principal companies in order to create or innovate new products; and (2) buyer responses regarding the assessment on demand aspect concerning on new product buying decision. This research uses qualitative method by phenomenology theoretical design that is: Fast Moving Consumer Goods (FMCG) principal within new product innovation, and FMCG wholesaler phenomenon within transactional buying-selling process between wholesalers and distributors. Data interpretation for this research is constructivism philosophy that is based on the location where buyer and seller, and companies do exist at traditional trade. The result identifies demand aspects those are demand of competitor product and categorical product, product segmentation, and demand of the product itself is: (1) several aspects that are valued by marketers in new product innovations. Aspects of demand are assessed by marketers for marketing mix strategy planning; and (2) the essences and buyer responses. Demand aspects are assessed by the buyer to estimate level of demand of new product within competition at internal or external condition.
\end{abstract}

Keywords: Demand, New products, Fast moving consumer goods (FMCG), Marketing mix, Business buyer behavior, Marketing strategies 


\section{Introduction}

Company's business growth can be achieved with various strategies, one of which is to innovate new products. Creation of new products aims to meet market demand. The company's marketing information specialists probably will use complex techniques to measure and forecast demand (Kotler and Armstrong, 2013). Likewise, estimating the demand for a new product innovated by Fast Moving Consumer Goods (FMCG) has a complexity in each of its business players. We have stipulates channel management of FMCG uses indirect channel system (see, Trihatmoko, Harsono, Wahyuni, and Haryono, 2016a and 2016b; Trihatmoko, 2016; Trihatmoko, Mulyani, and Lukviarman, 2018; Trihatmoko, Harsono, Wahyuni, Haryono, and Lukviarman, 2018). Thus, it can be assumed that the perceptive assessment of the demand for a new product is highly dependent on the interests of management.

This research, which regarding with demand, is simultaneously explore two management interests: (1) demand assessment by marketers in terms of new product innovation; and (2) demand assessment by distributors and wholesalers in transactional buying-selling of new products. The deepening of the various perspectives related to demand for the development of the concept of marketing mix and organizational buying behavior or business buyer behavior about new products. Meanwhile, research associated with demand for new products for FMCG business is still limited by previous researchers either from the perspective of the company owning the product brand (principal) or from the perspective of distributor and wholesaler as the product distributor.

Several studies from the point of view of principal interests, for example, were conducted by: (1) Hoek, Kearns and Wilkinson (2012) conducted research on new brand behavior in established markets; (2) Nijssen (2012) explore the success factors of new products through line extension strategy; (3) Sondergaard and Harmsen (2007) examines the market information in product development. However, their research has not revealed the demand assessment for a new product.

Some papers about consumer buying behavior on fast moving consumer goods (FMCG) industry recently focused on behavior of end users type. Meanwhile consumers organizational or business type seldom being explored, whereas customer of FGMC is business level. Business behavioral on FMCG industry has been researched, yet only figuring on relationship marketing and channel management (Verbeke, Bagozzi, and Farris, 2006; Pauwels, 2007; Kyle and Gruen, 2012; Wangungu and Gichira 2014; and Trihatmoko, Harsono, Wahyuni, and Haryono, 2016a and 2016b; Trihatmoko, 2016).

A general model for understanding organizational buying behavior by Webster and Wind (1972), encourage researchers to build the concept or within this paper we use term by Kotler and Armstrong, (2013) that is business buyer behavior. The concept building of business buyer behavior as showed by Stern and Reve (1980), Achrol, Reve and Stern (1983), Graski (1984), Dwyer, Schurr and Oh (1987), Aderson and Oliver (1987), Johnston and Lewin 
(1986), Lewin and Donthu (2004), Sashi (2009), Peter and Donnelly Jr. (2011), Solomon (2013), Kotler and Armstrong (2013), and Trihatmoko (2016). Yet, existing literature has not confirmed yet how business buyer behavior itself applied on FMCG distributor's customers, except by Trihatmoko (2016).

This paper selects the subject on marketer from FMCG companies, and business market for intermediary type that is wholesaler in Indonesian traditional trade. On 2010, a consulting company identifies intermediary customer of FMCG in Indonesian traditional trade reaches number 2.480.349 stores, include wholesaler, semi-wholesaler, and retail (Trihatmoko, 2016b; Trihatmoko, 2016; Trihatmoko, Mulyani, and Lukviarman, 2018). It means that object of FMCG is interesting and complex.

Buying-selling transaction between wholesalers and distributors in this paper will be focus about the transactional of new products as a result from the innovations of the companies, as a principal party. New product criterions are brand strategies product innovation (line extension, brand extension, multi-brand and new-brand) by principal party as the brand product owner (Kotler and Armstrong, 2013; Nijssen and Agustin, 2005; Nijssen, 1999; Trihatmoko, 2016; Trihatmoko, Mulyani, and Lukviarman, 2018). Revealing the product innovation strategy by principal and buying decision process of new product by wholesaler is the originality and the uniqueness of this paper. The first problem as a research question (RQ1) is how and why demand is assessed by the principal in new product innovation?

Although between wholesaler and distributor has been in relationship, yet the wholesaler is estimated has did not buy every single new product offers yet. Wholesaler is distributor customer, where their business to business (B2B) transaction are routine and sustained, so as the existing product buying categorized as straight-rebuy. When they deal with new product buying process from supplier, their buying process categorized as new-task purchase. Theoretically, new-task purchase is un-routine buying, when the product has not bought yet, high information gathering, product specs should be checked thoroughly, and supplier should be evaluated (Webster, Jr. and Wind, 1972; Jackson, Jr., et al., 1984; Wilkie, 1990; Evans and Berman, 1992; Sashi, 2009; Peter and Donnelly Jr., 2011; Solomon, 2013; Kotler and Armstrong, 2013). Robinson et al. (1967) punctuates for new-task purchase the buyer need to look for the information to explore alternative solution on organizational problem buying.

The description of new-task purchase describes the complexity of the new-task purchase situation, so as the research question of this paper limited on information gathering related to product competition that is demand aspects. Consumer demand refers to the characteristics and needs of end-consumers, industrial consumers, wholesalers and retailers, government institutions, international markets, and nonprofit institutions (Evans and Berman, 1992). The nature of demand, particularly whether demand for the product is generated within the buying organization or by forces outside of the organization (i.e., "derived" demand) as well as other characteristics of the demand pattern such as seasonal and cyclical fluctuations (Webster, Jr. and Wind,1972). Dwyer and Welsh (1985) identifies the variable of the channel output environment that are the variance of existing demand, the existing of competition, the 
availability of required resources, and the adaptability of supply to changes in demand. The question (RQ2) would be how and why buyer does assess the value of demand regarding new product buying decision process?

This research aims to identify, describe, and provide detail understanding about: (1) assessment of demand by the marketer as principal in terms of new product innovation; and (2) buyer responses regarding the assessment on demand aspect concerning on new product buying decision, this reiterates what Trihatmoko's research report (2016) has shown. This research is explorative study that uses qualitative method and to achieve the aim of the research.

The result of this research contributes providing widen concept of marketing mix and business buyer behavior, specifically on marketing of FMCG in traditional trade. As stated by Trihatmoko et al. (2016b) research on traditional trade interest also provides the advantages for managers and executive of multinational companies who interested build a carrier in Indonesia. Practitioners obtain the advantages practically to develop and apply marketing strategies.

\section{Theory and Literature}

\subsection{Product Innovation and Assessment of Demand}

New product innovation is theoretically called brand strategy, which consist of : line extension, brand extension, multi brand, and new brands (Kotler and Armstrong, 2013; Nijssen and Agustin, 2005; Nijssen, 1999; Trihatmoko, 2016; Trihatmoko, Mulyani, and Lukviarman, 2018). New products created from any types of strategy selected by the company, aims to position the product in the market. Various marketing management literature has stated that the strategy to achieve product success in the market refers to the conceptual basis of product, price, place, and promotion (4P's), otherwise known as marketing mix (Trihatmoko et al., 2016a and 2016b; Trihatmoko, 2016; Kotler and Armstrong, 2013; Ibidduni, 2011; Zineldin and Phillipson, 2007; Gronroos, 1997; and others).

Kotler and Armstrong (2013), technically has provided several methods to measure current market demand, namely total market demand, market demand area, and actual sales and market shares. The results of these calculations can be expected to be a reference for company in strategic product marketing decision making. Limited to this literature review, it can be predicted that among the aspects of demand with 4P's has a linkage in product innovation. Therefore, this research attempts to reveal the assessment of demand as to whether it is related to 4P's strategy planning.

\subsection{Business Buyer Behavior and Assessment of Demand}

This business buyer behavior study refers to the basic theory of behavior in marketing, namely agency theory. The characteristics of the relationship marketing approach that is explored are direct competitive relationship marketing between buyers and their suppliers 
(Trihatmoko, 2016; Trihatmoko, Harsono, Wahyuni, Haryono, and Lukviarman, 2018). Transactional position between the buyer and supplier is the realized outcome's of agency theory, or still in the context of B2B (Bergen, Dutta, and Walker, 1992; Trihatmoko, 2016; Trihatmoko, et al., 2018). Furthermore, the following is like the study conducted by Trihatmoko (2016) on previous research on business buyer behavior.

Business buyer behavior models describe that the environment is the stimulant to buying center in buying decision process (Webster, Jr. and Wind, 1972; Johnston and Lewin (1996); Kotler and Armstrong, 2013). The environment consists of: (1) Marketing environment those are product, price, place and promotion, and (2) Others environment those are economic, technological, political, cultural, and competitive (Kotler and Armstrong, 2013). Moreover in every step of buying decision process, buyer will response by considering the environment stimulant and determiner which plays in organizing buying it self (Robinson et al., 1967; Webster, Jr. and Wind, 1972; Wilkie, 1990; Evans and Berman, 1992; Johnston and Lewin 1996; Peter and Donnelly Jr., 2011; Solomon, 2013; Kotler and Armstrong, 2013). System of organization structure and individual characteristics take a role in buying decision process (Webster, Jr. and Wind, 1972; Garido and Gutierrez, 2004; Kotler and Armstrong, 2013).

Based on those literature reviews, the environment is the stimulant on buying decision. Yet, previous model has not showed yet what variables and how the environment assessed by buyer. Dwyer and Welsh (1985) state heterogeneous environment represent greater difficulty in obtaining and assimilating information about diversity environmental entities and when formulating effective strategic programs and responses when the diverse entities are relatively unstructured. Complexity of new task purchase situation and the heterogeneity of the environment information become the consideration as research focus start from competitive environment that is demand aspects.

This paper marks an assessment of the demand is the business buyer behavior series, since it is developed as a part of big and comprehensive research project on FMCG marketing. We publish some of the research project (see, Trihatmoko et al., 2016a and 2016b, and Trihatmoko et al., 2018). Moreover, series of business buyer behavior is expected will reveal other environment factors in every step of buying decision process.

Business buyer behavior becoming more complex, because buying decision process behaviorally cognitive through some steps. Peter and Donnelly Jr. (2011) arranges the steps these are assess the need, analyze the supplier, buying activity, and post purchase. On identifying need step Webster, Jr. and Wind (1972) providing an example that is the buyer considers re-sale or demand. Therefore it could be assumed that demand aspects is the competitive environment factors assessed by buyer on business need assessment step.

Stern and Reve (1980) illustrates economical-political framework to analyze supplier and distribution those are structure between internal economical environment and external economical environment related each other. Stern and Reve (1980) directing the perspective: external economical environment that is demand aspects as the prospective re-selling to 
business customer. Internal economical environment is wholesaler capability as channels function, in term of resources provider to face the obstacle and benefit of demand chance. Based on perspective review regarding need assessment and economical environment factor and competition, it can be estimated demand aspects and channel capability aspects is related each other.

Generally, business market has inelastic demand where total demand is not that much influenced by price fluctuation particularly in short term (Kotler and Armstrong, 2013). Evans and Berman (1992) figures out that wholesaler buy or handle merchandise and its subsequent resale to organizational users, retailers, and others wholesalers. Draganska and Klapper (2007) uses estimation analysis approach of demand and supply. Estimation structure of demand and supply becomes consumer decision factor in the interaction strategy between manufacturer and retailer, or contextually in this paper called as wholesaler. Buying process step is estimating certain product demand (Makhitha, 2015). Limited on demand perspective on above literature, accordingly the research reveals the type of demand and how the buyer responses in buying decision process.

\section{Method}

This research uses qualitative method by phenomenology theoretical design that is FMCG wholesaler phenomenon within a transactional (Proctor, 2005; Creswell, 2009; Jonker and Pennink, 2010; Saldana, 2011; Creswell, 2013; Gupta and Awasthy, 2015; Taylor, Bogdan, and DeVault, 2016). Phenomenology is research strategy approach to identify human experiences of certain phenomenon, in this case the marketers of FMCG companies, and the wholesalers of FMCG experiences on buying decision making of new product from many distributors company (Saldana, 2011; Creswell, 2013). Data interpretation for this research is constructionism/constructivism philosophy that is based on the location of buyer and seller in the traditional trade area (Saldana, 2011; Creswell, 2013; Hammersley, 2013; Gupta and Awasthy, 2015). We do agree with Fatchan (2011) that high level of qualitative research should combine various research approaches and the philosophical interpretation. We do believe combining strategic phenomenology and philosophical constructivism such as grounded theory, lead to build fresher conceptual framework and theoretical description.

Strategic phenomenology did as direction of Creswell (2013) illustrated by Moustakas (1994), those are: (1) identify the phenomenon, capture the experience of the researcher and collect the data from participants who experienced the phenomenon and analyze the data through the themes; (2) develop textual description regarding experience of the participants and structural description concerning how they experience the phenomenon, the situation and its context; (3) combine the textual description and structural description to deliver the essence of whole experiences of the participants. Constructivism of philosophy's view is to develop the subjective meanings of those experiences and those meanings directed to certain objects or things (Creswell, 2009). Therefore data analysis would be: (1) theme identification and description; (2) textual and structural description as premise and proposition; and (3) constructionist or conceptual model. 


\section{NI Macrothink}

Data obtained from marketers, buyers and sellers perception through in-depth interview. We have: (1) five marketers on the party of principal in his position as area sales manager and regional sales manager from the national and multinational companies (code, IM.1-5); (2) six wholesalers owner as buyer side (code, BI.1-6, Appendix A), and (3) from seller side we have three supervisors and managers of sales department distributor company (code, IBD.1-3, in Tirhatmoko's report, 2016). Sampling technique sued in this paper is snowball and purposive sampling method based on researcher's judgment, expert knowledge and convenience (Sekaran and Bougie, 2010; Proctor, 2005). This research conducted in "Solo-Raya" area, central Java, Indonesia, and as a follow-up to the expansion of the Trihatmoko's research report in 2016. Data processing started by doing reduction and data categorization, componential analysis, data coding, and axial coding, and in the end we form a model (Fatchan, 2011; Creswell, 2013; Jonker and Pennink, 2010).

Data recording based on interview the respondents and have been done through validation, field observation, and discussion. Data validation is done by triangulation process, member check, persistence observation, trial audit, data analysis (Creswell, 2013; Fatchan, 2011). Triangulation process, member check, persistence observation is an effort to build the credibility, meanwhile trial audit, data analysis is for analytic assessment to look for dependability and confirmability (Creswell, 2013). Field observation and discussion, i.e: (1) monitoring wholesaler daily activity; (2) following the salesman while offering the new product; (4) discussing the result of the interview with all informant; (5) discussing tentative research result with manufacturer practitioner such as senior manager and director in multinational company; etc. Observation, interview, and mini focus group discussion conducted with each informant by simultaneous and ongoing process according to the informant's experience and the field phenomenon.

Obtaining deep information from the perception and different phenomenon is the strength of data validation of this qualitative research to build research credibility (Creswell, 2013; Taylor et al., 2016). Over all this research procedure done and successfully reveal the aim of the research, so as the result discussion could be done holistically (Fatchan, 2011; Creswell, 2013; Gupta and Awasthy, 2015). The detailed methodological explanation in this paper is at the same time as a review of the research method for the serial studies for business buyer behavior and marketing mix in the next paper that "will be done" by the TEM-D (Trihatmoko Economic and Management Development) study cluster. 


\section{Findings}

\subsection{Product Innovation and Assessment of Demand}

4.4.1 Theme Identification and Description

Table 1. Level of Demand Theme Identification

\begin{tabular}{|c|c|c|c|}
\hline Informant & $\begin{array}{lr}\text { Competitors } & \& \\
\text { Categorical } & \text { Products } \\
\text { Demand } & \end{array}$ & Product Segmentation & New Product Demand \\
\hline IM.1 & $\begin{array}{l}\text { There is Wardah, Sariayu, } \\
\text { and also La Tulipe }\end{array}$ & The segment & $\begin{array}{l}\text { will provide product } \\
\text { knowledge }\end{array}$ \\
\hline IM.2 & $\begin{array}{l}\text { compared to competitors; } \\
\text { the category }\end{array}$ & $\begin{array}{l}\text { The price range, from some } \\
\text { price to some price }\end{array}$ & Demand from its customers \\
\hline IM.3 & $\begin{array}{l}\text { Compared with the } \\
\text { competitor }\end{array}$ & In terms of segment, & $\begin{array}{l}\text { Help wholesalers to launch the } \\
\text { goods }\end{array}$ \\
\hline IM.4 & $\begin{array}{l}\text { Those are teh Javana, teh } \\
\text { Pucuk }\end{array}$ & Those are in our segment & The retail demand is strong \\
\hline IM.5 & $\begin{array}{lll}\begin{array}{l}\text { Compared } \\
\text { competitor }\end{array} & \text { with our } \\
\end{array}$ & Desired by the society & Already high demand \\
\hline $\begin{array}{l}\text { Strategic } \\
\text { Planning }\end{array}$ & $\begin{array}{l}\text { Advantages and benefits of } \\
\text { the product; we are more } \\
\text { expensive; our quality is } \\
\text { better }\end{array}$ & $\begin{array}{l}\text { The usability, its function; In } \\
\text { terms of pricing; can be sold / } \\
\text { bought; issuing sample; } \\
\text { products of powder }\end{array}$ & $\begin{array}{l}\text { Many promotions; Penetration } \\
\text { to market; Activation team } \\
\text { placed; Help wholesale; } \\
\text { advantages of the product }\end{array}$ \\
\hline
\end{tabular}

The launching process of new products from FMCG industry through the planning process that started from the creation of new products as a form of product innovation. The results revealed that the company's strategy for innovating their new products was based on the assessment of market demand. New product innovation is expressed as an antecedent of business buyer behavior on various marketing mix strategies (4P's: product, price, place, promotion). The excerpt of an interview transcript of each level of demand theme relates to the marketing mix strategy policy expressed by informant marketers (Table 1).

- Competitors \& Categorical Products Demand

Marketer phenomena identify that their product innovation has a market demand prospect based on competitors \& categorical products demand. The expectation of new product demand is evaluated based on product and price strategy planning. Here is an example of marketers' perceptions.

"... of this product compared to the competitors, the advantage is..... the advantages and benefits of this product that will make the store interested, is., We are referring to the customer base data we have collected then put this product into its category” (IM.2)

“...when compared with competitors we are usually more expensive because of our better quality...”(IM.3)

"If it's viewed in terms of competitive price, our price is competitive, Sir. For example, the price of Si Sri tea that once came out, 25.000 each carton, Sir, contains 12 bottles, Teh Javana and Teh Pucuk are also the same. The same glass tea, which distinguishes is 
in the program pack.. Teh Gelas is also the same, he only difference is the program, Sir.” (IM.4)

\section{- Rationality of Competitors \& Categorical Products Demand}

New product innovation is positioned to have superior quality and price compared with competitors \& categorical products demand. Product quality planning and new product pricing strategies are marketers' beliefs to expect new product demand to be marketed. New products that have the quality and price excellence compared with competitors \& categorical products, is expected to get a response from the market. In contrast, the quality and price of new products that do not compete with competitors and categorical products are expected to be less responded by the market.

\section{- Product Segmentation}

Marketers' phenomenon identifies that their product innovation has a market demand prospect based on product segmentation. Evaluation of product segmentation by marketers is estimated to be in accordance with competitors \& categorical products demand. Expectations on new product demand are evaluated based on strategy planning of product, pricing and promotion. The description is as presented by the following marketers.

"Yes, the salesman is... For the example, if there are new products, the salesman will be educated first, will be in briefing first. They will be told that there is a new product, the function and also the segment.” (IM.1)

"For a new product we certainly issue a sample, that the sample will be used by the BTL team led by one of them, by Ms. Lita. The sampling is done to educate the user. The user is in accordance with the target market, the example, whether to government agencies or in the students in the elementary school where. ... like that in our segment" (IM.4)

"From the factory, they will usually ask the market survey first, Sir, what is needed by the rich society ... ... for the example if we want to launch a product in the form of powder, we first conducted market survey related to what are the needs and desires of the market...." (IBP.5).

\section{- Rationality of Product Segmentation}

New product innovation is positioned based on its market segmentation. Product quality and new product pricing planning strategies, as well as promotional support in the form of product samples become marketers' confidence to expect new product demand to be marketed. The quality and price of the products, as well as the promotion of new products that fit their segmentation targets, are expected to get a response from the market. In contrast, the quality and price of new products, as well as promotional forms of products that do not compete with segmentation, are expected to be less responded by the market. 
- Expectation of New Product Demand

The phenomenon of marketers in innovating new products has devised a strategy of "4P's" marketing mix. In addition to product content, price and promotion that the expectation of new product demand is also designed by marketers about the penetration of product distribution (P: place). Placement of products will be done through distributors such as distributors, wholesalers and retailers, as explained by the following marketers.

"This beauty consultant will give the product knowledge to the user directly, but later for the wholesaler, given from the distributor salesman. ... Ya, about the total target, because this product is still new, if not much education and not much promotion, people will not know, Sir...” (IM.1)

"It is usually there, because this is the way of market penetration ..., for example posters and all kinds of that ... But with all the advertising spots and he already saw, then came the demand from customers, ...” (IM.2)

"Then the activation team is placed in one of the points we designate to distribute from wholesalers to retailers and be there to help wholesalers to issue items” (IM.3)

\section{- Rasionality of Expentation of New Product Demand}

Based on competition and product segmentation, the next task of marketers is to encourage the creation of new product demand. The expectation of new product demand is based on 4P's strategy planning whether it is in the process of manufacturing new products or when launching the new products. New product innovation that applying marketing mix strategy appropriately and aggressively is expected to encourage the creation of new product demand itself. Conversely, the marketing mix strategy that is less precise and passive is expected to slow or fail the new product demand itself.

\subsubsection{Premise and Minor Proposition}

Based on textual description of each level of demand theme above, therefore it can be described structurally as premises (P.a--) and minor proposition (P1-4). Structural description made for illustrate the variability correlation level of demand which is valued by marketers in terms of new product innovation. Level of demand related to 4P's strategy planning describes the antecedents of business buyer behavior exploration in this study. Here are the data analysis result after axial coding and componential analysis procedure, thus it can showed conceptually or theoretically.

Firstly, (P.a) New product innovations are created by companies based on competitors \& categorical products demand. (P.b) Competitors \& categorical products demand become the reference of product segmentation. (P.c) Competitors \& categorical products demand become the reference to 4P's strategy planning. (P.d) Product segmentation becomes the company's foundation in $4 \mathrm{P}$ 's strategy planning.

P1: Competitor and categorical products demand determine 4P's strategy planning. 
P2: Competitor and categorical products demand determine new product segmentation.

P3: New product segmentation determine 4P's strategy planning.

Second, (P.a) 4P's strategy planning as the company's efforts to create market demand for their product innovation. (P.b) The accuracy and aggressiveness of the 4P's strategy as a fundamental for the marketer to expect the demand for new products created.

P4: 4P's strategy planning determines the expectation of new product demand.

By structural description or those prepositions, conceptually could be constructed demand valuation within product innovation (see, Figure 1).

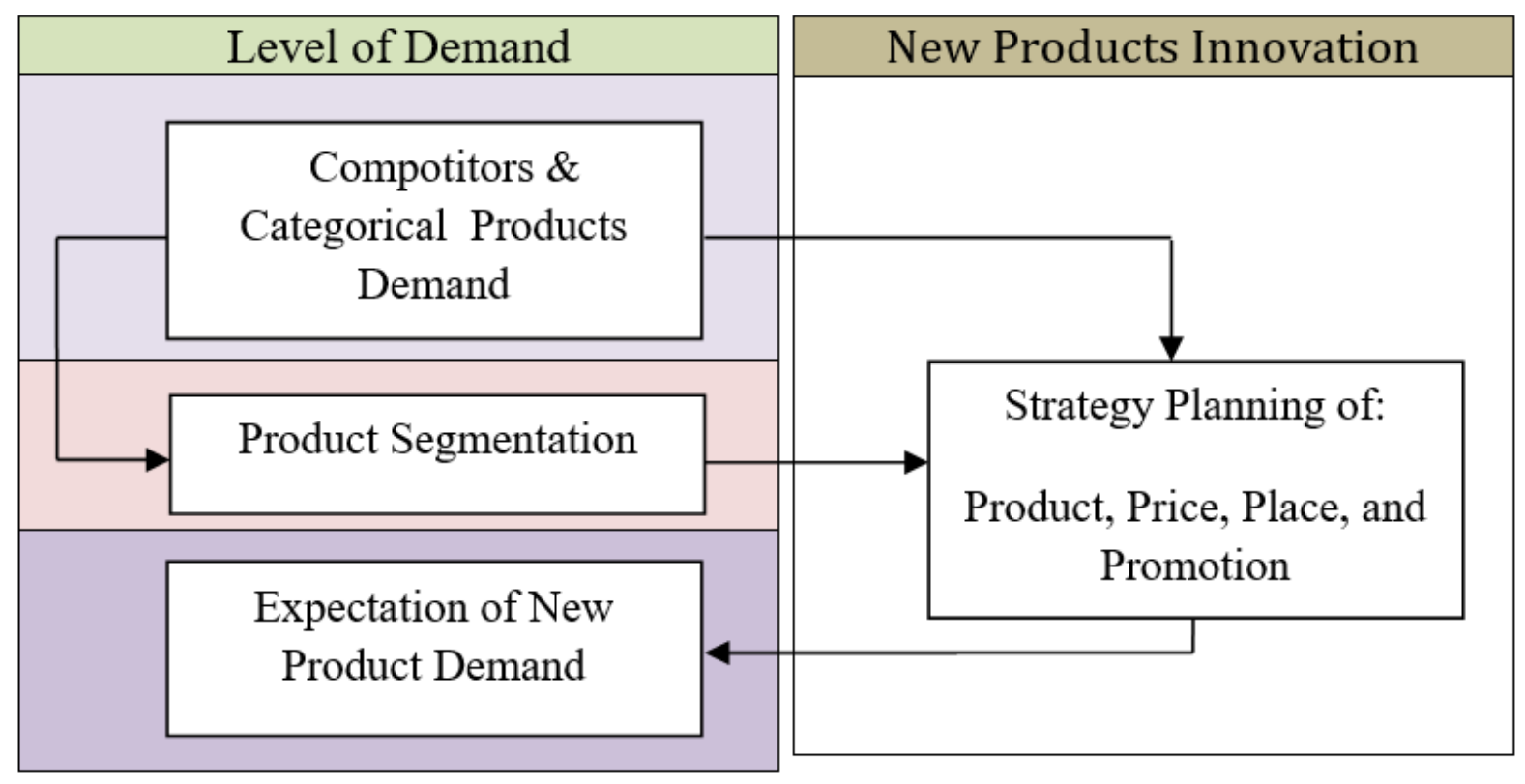

Figure 1. Assessment Level of Demand Model for New Product in The Product Innovation

\subsection{Business Buyer Behavior and Assessment of Demand}

Assessment of market demand in the perspective of business buyer behavior, we need to reopen Trihatmoko (2016) research report (Appendix). The conceptualization and theorization in the research report is considered important to be presented in this paper. This is so that understanding of the aspects of demand can be explored more deeply. Thus, in all exposures in the attachment (Appendix), it is used to provide answers to RQ2, so that it will fulfill this study in this paper.

\section{Discussion and Implications}

\subsection{Product Innovation and Assessment of Demand}

Level of demand assessment conceptualization in product innovation contributes to the concept of 4P's strategy planning. The development of demand level is proposed as an 
extension to the marketing mix literature by Trihatmoko et al. (2016a and 2016b); Kotler and Armstrong (2013), Ibidduni (2011), Zineldin and Phillipson (2007), Gronroos (1997), and so on, specifically in FMCG marketing on segmentation targets in traditional markets.

Level of demand assessment conceptualization according to the business interests of the product makers and the merchants provide a new perspective on demand, especially related to new product innovation on FMCG business. Therefore, the results of this study will have implications for strategic studies in determining brand strategy by Kotler and Armstrong (2013), Nijssen and Agustin (2005), Nijssen (1999), Trihatmoko (2016), and Trihatmoko, Mulyani, and Lukviarman, 2018).

\subsection{Business Buyer Behavior and Assessment of Demand}

Level of demand assessment conceptualization in the business buyer behavior contribute in explaining the concept of Peter and Donnelly Jr. (2011) concerning to organizational needs valuation specifically on new product need by FMCG wholesaler in traditional trade. This finding in line with Webster, Jr. and Wind (1972), Evans and Berman (1992), Draganska and Klapper (2007), Kotler and Armstrong (2013) also Weele, 2005 within Makhitha (2015) states about demand aspect as the consideration business market within buying product process. This finding is in accordance with Webster, Jr. and Wind (1972), Johnston and Lewin (1996) Kotler and Armstrong (2013) which identifies economic factor is stimulant for organizing buying in the business buyer behavior concept.

This research result novelty are identifying in detail and theoretically describing and also abstracting become new construction of the new product demand related to competition and internal situation of distributor in business buyer behavior. This research result philosophically re-constructs, so as implicate theoretically in business buyer behavior as state below (Trihatmoko, 2016):

First, these research result shows : (1) identifies level of demand variability includes competitor product and categorical product, product segment, and customer demand existence are the aspects which determine product buying decision; (2) indentifies and describes linkage among level of demand variability to wholesaler customer coverage related to prospective product selling; and (3) identifies and put in place environment that is external economic about the level of demand variability to determine buying decision. This is related about internal economical environment about customer coverage and competition of selling product turnover. Meanwhile existing literature limited on level of demand as consideration or stimulant of buying decision, so as has not described theoretically its rationality by Webster, Jr. and Wind (1972), Evans and Berman (1992), Johnston and Lewin (1996); Draganska and Klapper (2007), Kotler and Armstrong (2013), and Weele, 2005 in Makhitha (2015).

Second, the result identifies specifically wholesaler customer coverage as internal economical environment and level of demand is the external environment factor, both of them related in business buyer behavior. Meanwhile Stern and Reve's (1980) framework limitedly shows 
correlation between external and internal economical environment in the distribution channel structure, also Dwyer and Welsh (1985) narrowly discussing on environment characteristic correlate with distributor configuration.

\section{Conclusion}

\subsection{Product Innovation and Assessment of Demand}

The result of the research identifies that the level of demand aspect of product competitor and categorical product demand, product segment becomes the basis of product innovation which is covered in $4 \mathrm{P}$ 's strategy planning. The $4 \mathrm{P}^{\prime}$ 's strategy is aggressively designed to expect new product demand itself. The three aspects of the level of demand is a product competition in one category. Based on those findings, major proposition of this study are:

P1: The level of demand aspect in one product category encourages new products innovation within the 4P's strategy.

P2: Innovation of new products within the 4P's strategy will have an impact on product demand competition in one product category.

Thus, can be concluded: (1) New product innovation by principal has been planned in 4P's strategy; (2) Planning of 4P's is done by assessing the aspects of product level of demand in one category; and (3) The reason that a product's 4P's strategy is designed, is to meet market needs and also be able to compete with products in one category.

\subsection{Business Buyer Behavior and Assessment of Demand}

The result reveals buyer's phenomenon in estimating demand aspect, while reacting on new product offering from the supplier (see, the premises and minor propositions in Appendix A). The result confirms buyer validates their needs by assessing new product feasibility to business environment. Buyer estimates external economical environment factor that is level of demand in market competition. Level of demand itself consists of competitor product and categorical product demand, product segment, and current new product demand. Level of demand valuation refers to competitor product and categorical product demand, product segment related customer coverage. Competitor product and categorical product demand, product segment, and current new product demand defines buying decision. Buyer do valuation of the level of demand is to estimate prospective new product selling turnover. Based on those findings, major proposition of this study are:

P1: External economical environment factor or market competition about level of demand aspect include competitor product and categorical product, product segmentation, and new product demand itself defines buying decision determined by buyer.

P2: External economical environment aspects and internal economical environment aspect related each other and influence each other.

Thus, can be concluded: (1) Buyer does new product demand valuation by observing external 
economical factor and demand aspect competition, and prospective selling turnover and internal economical environment factor as channel capability aspects; and (2) The reason buyer does assess external economical environment factor, competition, and internal economical factor as the base to estimate new product selling turnover.

The overall research results reveal that there is similarity in assessment on the aspect of the level of demand either by the principal or by the merchant. They assess demand by identifying competitor product and categorical product demand, product segment, and new product demand itself. However, the relationship between variables to assess the level of demand for new products has a distinction between principal and wholesale interests. Principal assesses the demand in context to develop 4P's strategy planning, while wholesale is in the context of the decision-making process. In accordance with the preliminary predictions of this paper, it can be concluded that the assessment of demand is highly dependent on the perspective of business interests of each party

\section{Recommendations}

The similarity of aspects in level of demand is covered in business buyer behavior and product innovation construction. Therefore, this paper direct to FMCG business practitioner to market the new product. First, marketer as maker/owner suggested in creating new product: (1) They should review existing competitor and similar categorical product; (2) They should have clear segment, particularly middle-low consumer in traditional trade. Its aim is every single product release could compete with existing product through wholesaler role in traditional trade.

Second, salespeople suggested developing new product distribution in retailer level before sell the new product to wholesaler. The purpose is to convince wholesaler that new product demand mechanism for retailer as potential customer has been formed. Third, buyer suggested being precise assessing market potential for every new product offering from supplier. The purpose is for making sure the product will be bought salable, specifically through the customer in traditional trade.

\section{Limitations and Future Research}

First, marketing mix research has some limitations: (1) focused only on assessing the variability of demand for a new product innovation by the FMCG business principal; (2) The $4 \mathrm{P}^{\prime}$ s strategy is perceived as strategic planning in terms of new product innovation, meaning that any element of 4P's has not been disclosed in detail; and (3) the product segmentation perspective is targeted to the product marketing target in the traditional trade. Hence, the different stages of the execution of the 4P's elements towards its target market in the framework of new product innovation have the opportunity to develop a different concept with the conceptualization of the results of this study.

Second, business buyer behavior research has some limitations: (1) B2B of new product transactional between distributors and wholesalers FMCG industry in traditional trade; and (2) 
Exploration center on demand aspects variability. Therefore, dissimilar object and subject of research, exploration center, will provide different result.

Generally, this qualitative research and design uses phenomenology and constructivism cannot be generalized in marketing mix in all manufactures business, and business buyer behavior in all business market, and the characteristic of direct competitive relationship marketing. The proposed theoretical proposition is holistic, therefore quantitative research might test propositions of result concept of this research.

\section{Acknowledgments}

The authors extend their gratitude and appreciation to the research participants of FMCG's business units in the field: manufacturers, distributors, promotional agencies, wholesalers and retailers. The gratitude also delivered to they who have contributed directly or indirectly to this research, although it cannot be mentioned one by one.

\section{References}

Achrol, R. S., Reve, T., \& Stern, L. W. (1983). The Environment of Marketing Channel Dyads: A Framework for Comparative Analysis. The Journal of Marketing, 47(4), 55-67. Retrieved from http://www.jstor.org/stabel/251399

Bergen, M., Dutta, S., \& Walker, Jr. O. C. (1992). Agency Relationships in Marketing: A Review of the Implications and Applications of Agency and Related Theories. Journal of Marketing, 56(3), 1-24. https://doi.org/10.2307/1252293

Creswell, J. W. (2009). Research Design. Qualitative, Quantitative and Mixed Methods Approaches. Third Edition SAGE Publication. Achmad Fawaid. 2016. Research Design. Pendekatan Kualitatif, Kuantitatif dan Mixed. Edisi Kelima. Pustaka Pelajar Yogyakarta. Indonesia.

Creswell, J. W. (2013). Qualitative Inquiry \& Research Design: Choosing Among Five Approaches (3rd ed.). SAGE Publication.

Draganska, M., \& Klapper, D. (2007). Retailer Environment and Manufacturer Competitive Intensity. Journal of Retailing, 83(2), 183-198. https://doi.org/10.1016/j.jretai.2007.01.001

Dwyer, F. R., \& Welsh, M. A. (1985). Environmental Relationships of The Internal Political Economy of Marketing Channels. Journal of Marketing Research, 22(4), 397-414. Retrieved from http://www.jstor.org/stable/3151585

Evans, J. R., \& Berman, B. (1992). Marketing. New York, USA: Macmillan Publishing Company.

Fatchan, H. A. (2011). Metode Penelitian Kualitatif. Jenggala Pustaka Utama, Surabaya, Indonesia.

Garrido-Samaniego, M. J., \& Gutierrez-Cillan, J. (2004). Determinants of Influence and 
Participation in The Buying Center. An Analysis of Spanish Industrial Companies. The Journal of Business \& Industrial Marketing, 19(5), 320-336. https://doi.org/10.1108/08858620410561051

Gronroos, C. (1997). Keynote Paper from Marketing Mix to Relationship Marketing Towards a Paradigm Shipt in Marketing, Management Decision, 35(4), 322-339. Retrieved from http://search.proquest.com/docview/212059958?accountid=44945

Gupta, R. K., \& Awasthy, R. (2015). Qualitative Research in Management. SAGE Publications India Pvt Ltd., New Delhi, India.

Hammersly, M. (2013). What is Qualitative Research? Bloomsbury Publishing Plc., London, UK.

Hoek, J., Kearns, Z., \& Wilkinson, K. (2003). A New Brand's Behavior in an Established Market, Journal of Product and Brand Management, 12(1), 52-63. Retrieved from http://www.emeraldinsight.com/1061-0241.htm

Ibidunni, O. S. (2011). Marketing Mix as Tools for Achieving Competitive Advantage in Nigerian Market Place: Multi-National and Indigenous and Companies in Perspective. Journal of Marketing Development and Competitiveness, 5(7), 81-94.

Jackson, D. W., Keith, J. E., \& Burdick, R. K. (1984). Purchasing Agents’ Perceptions of Industrial Buying Center Influence: A Situational Approach. Journal of Marketing, 48(4), 75-83. Retrieved from http://www.jstor.org/stable/1251512

Johnston, W. J., \& Lewin, J. E. (1996). Organizational Buying Behavior: Toward an Integrative Frame Work. Journal of Business Research, 35, 1-15. Retrieved from https://www.sciencedirect.com/science/.../014829639400077

Jonker, J., \& Penning, B. (2010). The Essence of Research Methodology. Springer, Berlin, Germany.

Keegan, S. (2009). Qualitative Research. Kogan Page Ltd, London, UK.

Kotler, P., \& Armstrong, G. (2013). Principles of Marketing. Pearson Education Limited, Harlow, England.

Kyle, D., \& Gruen, T. W. (2004). The Use of Category Management Practices to Obtain a Sustainable Competitive Advantage in the Fast Moving Consumer Goods Industry. Journal of $\begin{array}{lllll}\text { Business } \quad \& \quad \text { Industrial } & \text { Marketing, } & \text { 19(7), }\end{array}$ https://doi.org/10.1108/08858620410564391

Lazuardi, A. L. (2015). Penelitian Kualitatif \& Desain Riset: Memilih di antara Lima Pendekatan. Edisi Pertama. Pustaka Pelajar Yogyakarta. Indonesia.

Lewin, J. E., \& Donthu, N. (2005). The Influence of Purchase Situation on Buying Center Structure and Involvement: A Select Meta-Analysis of Organization Buying Behavior 
Research. Journal of Business Research, 58, 1381-1390. https://doi.org/10.1016/j.jbusres.2004.09.004

Makhitha, K. M. (2015). Understanding the Organisational Buyer Behaviour of Craft Retailers In South Africa. The Journal of Applied Business Market, 31(2), 501-514. Retrieved from https://www.researchgate.net/.../281717031_Understanding_The_Organisational_Buyer

Nijssen, E. J. (1999). Success Factors of Line Extensions of Fast Moving Consumer Goods. Journal of Marketing, 33(5/6), 450-474. https://doi.org/10.1108/03090569910262044

Nijssen, E. J., \& Agustin, C. (2005). Brand Extension: A Manager's Perspective. Journal of Brand Management, 13(1), 33-49. https://doi.org/10.1057/palgrave.bm.2540244

Parsons, A. L. (2002). What Determines Buyer-Seller Relationship Quality? An Investigation from The Buyer's Perspective. Journal of Supply Chain Management, 38(2), 4-12. Retrieved from https://onlinelibrary.wiley.com/.../j.1745-493X.2002.tb0012

Pauwels, K. (2007). How Retailer and Competitor Decisions Drive the Long-Tem Effectiveness of Manufacturer Promotion for Fast Moving Consumer Goods. Journal of Retailing, 83(3), 297-308. Retrieved from https://www.sciencedirect.com/science/.../S00224359070001

Peter, J. P., \& Donnelly, Jr. J. H. (2011). Marketing Management. The McGraw-Hill Companies, Inc., New York, USA.

Proctor, T. (2005). Essentials Marketing Research. Pearson Education Limited, Harlow, England.

Robinson, P., Wind, Y., \& Faris, C. W. (1967). Summary Information: Industrial Buying and Creative Marketing. Allyn \& Bacon United States. Retrieved from http://www.provenmodels.com/549/bygrid-framwork/c_

Saldana, J. (2011). Fundamentals of Qualitative Research. Oxford University Press, Inc., New York, USA.

Sashi (2009). Buyer Behavior in Business Markets; A Review and Integrative Model. The Journal of Global Business Isues, 3(2), 129-138. Retrieved from https://www.highbeam.com/doc/1P3-1861170161.html

Sekaran, U., \& Bougie, R. (2010). Research Methods for Business. Fifth Edition, Jhon Wiley \& Sons Ltd., West Sussex, United Kingdom.

Solomon, M. R. (2013). Consumer Behavior. Pearson Education Limited, Harlow, England.

Sondergaard, H. A., \& Harmsen, H. (2007). Using Market Information in Product Development, Journal of Consumer Marketing, 24(4), 194-201. https://doi.org/10.1108/07363760710755986

Stern, L.W., \& Reve, T. (1980). Distribution Channels as Political Economies: A Framework 
for Comparative Analysis. Journal of Marketing, 44(3), 52-64. Retrieved from http://www.jstor.org/stable/1251111

Tang, Y. C., Wang, Y. M., \& Huang, J. Y. (2014). Optimal Promotional Strategy for Intra-category Cross-selling An Application to Culinary Products in Taiwan. British Food Journal, 116(1),80-90. https://doi.org/10.1108/BFJ-12-2011-0306

Taylor, S. J., Bogdan, R., \& DeVault, M. L. (2016). Introduction to Qualitative Research Methods. John Wiley \& Son, Inc. Canada.

Trihatmoko, R. A. (2016). Proses Keputusan Pembelian Produk Baru oleh Grosir Industri Fast Moving Consumer Goods (FMCG) di Pasar Tradisional. Disertasi Pascasarjana Program Studi Doktor Ilmu Ekonomi, Universitas Sebelas Maret, Surakarta, Indonesia. Retrieved from https://digilib.uns.ac.id/dokumen/detail/57395/Proses-Keputusan-Pembelian-Produk-Baru-ole h-Grosir-Industri-Fast-Moving-Consumer-Goods-FMCG-di-Pasar-Tradisional

Trihatmoko, R. A., Harsono, M., Wahyuni S., \& Haryono, T. (2016a). Buyer-Seller Relationship Construction in The Business Buyer Behavior: Wholesaler and Distributor Fast Moving Consumer Goods (FMCG) Industry in Indonesian Market Place. International Journal of Research in Commerce \& Management, 7(5), 24-33. Retrieved from http://ijrcm.org.in/article_info.php?article_id=6618

Trihatmoko, R. A., Harsono, M., Wahyuni S., \& Haryono, T. (2016b). The Confine of Efficient Contract Between Principals and Distributors Perfectly Control of Marketing Mix Strategies: Channel Management Perspective of Fast Moving Consumer Goods (FMCG) Industries in Indonesian. International Journal of Research in Commerce, Economics \& Management, 6(9), 31-36. Retrieved from http://ijrcm.org.in/article_info.php?article_id=7013

Trihatmoko, R. A., Harsono, M., Wahyuni, S., Haryono, T., \& Lukviarman, N. (2018). Structure of Channel Management and Agency Theory: Relationship Marketing Approach for Fast Moving Consumer Goods (FMCG) Business. Research in Business and Management, 8(2), 25-37. https://doi.org/10.5296/rbm.v5i2.13413

Trihatmoko, R. A., Mulyani, R., \& Lukviarman, N. (2018). Product Placement Strategy in the Business Market Competition: Studies of Fast Moving Consumer Goods. Business and Management Horizon, 6(1), 150-161. https://doi.org/105296/bmh.v6i1.13239

Verbeke, W., Bagozzi, R. P., \& Farris, P. (2006). The Role of Key Account Program, Trust, and Brand Strength on Resource Allocation in Channel of Distribution. Journal of Marketing, 40(5/6), 502-532. https://doi.org/10.1108/03090560610657813

Wangungu, J., \& Gichira, R. (2014). Influence of Supply Chain Management Practices to Branding In Fast Moving Consumer Goods Industry in Kenya: A Case Study of Thika Small and Medium Enterprises. International Journal of Academic Research in Business and Social Sciences, 4(9), 251-264. URL: https://doi.org/10.6007/IJARBSS/v4-i9/1154 
Webster, F. E., Jr., \& Wind, Y. (1972). A General Model for Understanding Organizational Buying Behavior. Journal of Marketing, 36(2), 12-19. Retrieved from http://www.jstor.org/stable/1250972

Wilkie, W. L. (1990). Consumer Behavior. John Wiley \& Sons. Inc., Canada, USA.

Williems, M. R., \& Attaway, J. S. (1996). Exploring Salesperson's Consumer Orientation as a Mediator of Organizational Culture's Influence on Buyer-Seller Relationships. The Journal of Personal Selling \& Sales Management, 16(4), 33-52. Retrieved from https://www.tandfonline.com/.../08853134.1996.10754072

Zineldin, M., \& Philipson, S. (2007). Kotler and Borden are not Dead: Myth of Relationship Marketing and Truth of the 4Ps. Journal of Consumer Marketing, 24(4), 239-241. https://doi.org/10.1108/07363760710756011

\section{Appendix A}

\section{Theme Identification and Structural Description}

Table 2. Level of Demand Theme Identification

\begin{tabular}{|c|c|c|c|}
\hline Informant & $\begin{array}{l}\text { Competitors \& categorical } \\
\text { products demand }\end{array}$ & Product Segmentation & New product demand \\
\hline BI.1 & $\begin{array}{l}\text { Balanced competitor does } \\
\text { exist }\end{array}$ & $\begin{array}{l}\text { This is not the segment.... } \\
\text { This is not the market of my } \\
\text { merchant }\end{array}$ & $\begin{array}{l}\text { The merchant is easy if } \\
\text { saleable }\end{array}$ \\
\hline BI.2 & $\begin{array}{l}\text { If it is similar product I will } \\
\text { not sell }\end{array}$ & $\begin{array}{l}\text { What is the favorite of the } \\
\text { customer? }\end{array}$ & $\begin{array}{l}\text { The most important matter } \\
\text { customer looking for me }\end{array}$ \\
\hline BI.3 & $\begin{array}{l}\text { Whether I will sell similar } \\
\text { product or not }\end{array}$ & $\begin{array}{l}\text { Segment: there is the } \\
\text { segment ... i.e brand of } \mathrm{BC} \\
\text { milk is already exist }\end{array}$ & $\begin{array}{l}\text { The product is available and } \\
\text { sold }\end{array}$ \\
\hline BI.4 & $\begin{array}{l}\text { Other's product? many people } \\
\text { consume the product or they } \\
\text { do not know at all }\end{array}$ & $\begin{array}{l}\text { I prefer to my customer } \\
\text { segment }\end{array}$ & $\begin{array}{l}\text { If the product salable, why } \\
\text { we should not provide }\end{array}$ \\
\hline BI.5 & Refers to other salable product & Depends on people need & $\begin{array}{l}\text { After end consumer asking } \\
\text { about the product }\end{array}$ \\
\hline BI.6 & $\begin{array}{l}\text { I will see the competitor or the } \\
\text { similar category }\end{array}$ & $\begin{array}{l}\text { What drive me is product } \\
\text { segment itself }\end{array}$ & $\begin{array}{l}\text { Is there any demand from the } \\
\text { customer }\end{array}$ \\
\hline
\end{tabular}

Source: Trihatmoko’s research report (2016)

Premise and Minor Proposition

Based on textual description of each level of demand theme above, therefore it can be described structurally as premises (P.a--) and minor proposition (P1-9). Structural description made for illustrate the correlation of buyer responses variable's essence concerning the new product demand level. Here are the data analysis result after axial coding and componential analysis procedure, thus it can showed conceptually or theoretically.

Firstly, (P.a) Demand for competitor product and categorical product as the new product buying decision process's consideration. (P.b) New product segment become a consideration 
to estimate new product demand level in buying decision process. (P.c) Current new product demand as the buyer consideration to estimate new product demand level in buying decision process.

P1: Demand for competitor product and categorical product determine buying decision.

P2: New product segment determine buying decision.

P3: New product demand determine buying decision.

Second, (P.a) Buyer assesses level of demand for new product based on demand for competitor product and categorical product that available in store at that time. (P.b) Buyer assesses level of demand for new product based on new product segment. (P.c) Wholesaler customer coverage in traditional trade is the retailer which targeting middle-low consumer.

P4: Demand for competitor product and categorical product determine estimated new product demand.

P5: New product segment determine estimated new product demand.

P6: New product segment determine conformity of customer coverage.

Third, (P.a) Wholesaler customer coverage in traditional trade is the retailer which targeting middle-low consumer. (P.b) Character of wholesaler customer coverage lead as buyer reference to estimate prospective new product selling turnover. (P.c) Demand for competitor product characteristic "continuous customer or rarely to buy customer" lead as buyer reference to estimate prospective new product selling turnover. (P.d) Indication for wholesaler customer demand intensity of new product itself lead as buyer reference to estimate prospective new product selling turnover.

P7: Characteristic of customer coverage determine prospective new product selling turnover, through new product demand.

P8: Characteristic of competitor product and categorical product turnover determine prospective new product selling turnover, through new product demand.

P9: Indication for new product demand intensity determine prospective new product selling turnover.

By structural description or those prepositions, conceptually could be constructed demand valuation within business buyer behavior (see, Figure 2). 


\section{Macrothink}

\section{Appendix B}

\section{Constructionist of Business Buyer Behavior}

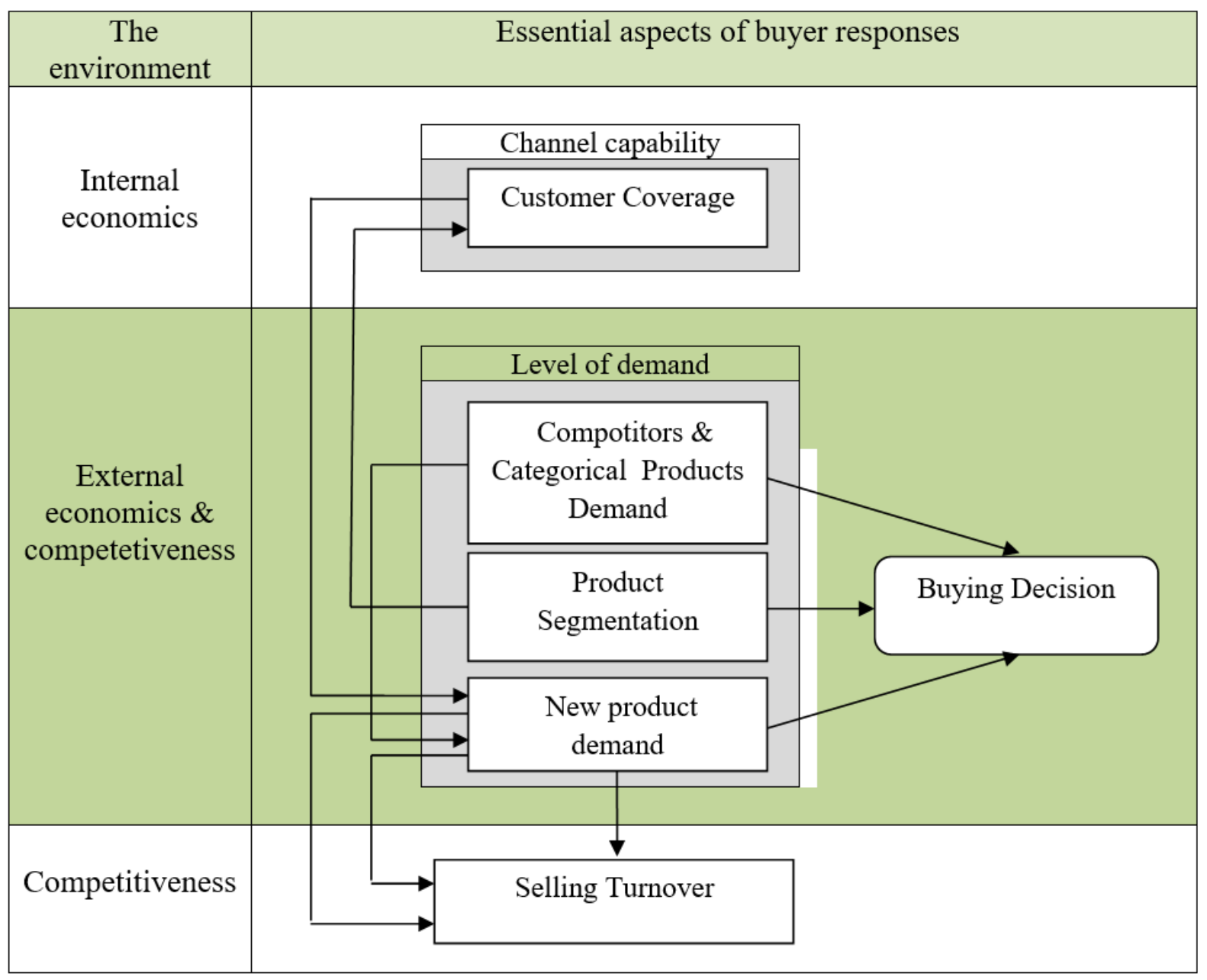

Figure 2. Assessment Level of Demand Model for New Product in The Business Buyer Behavior

Source: Trihatmoko’s research report (2016)

\section{Copyright}

Copyright for this article is retained by the author(s), with first publication rights granted to the journal.

This is an open-access article distributed under the terms and conditions of the Creative Commons Attribution license (http://creativecommons.org/licenses/by/4.0/). 